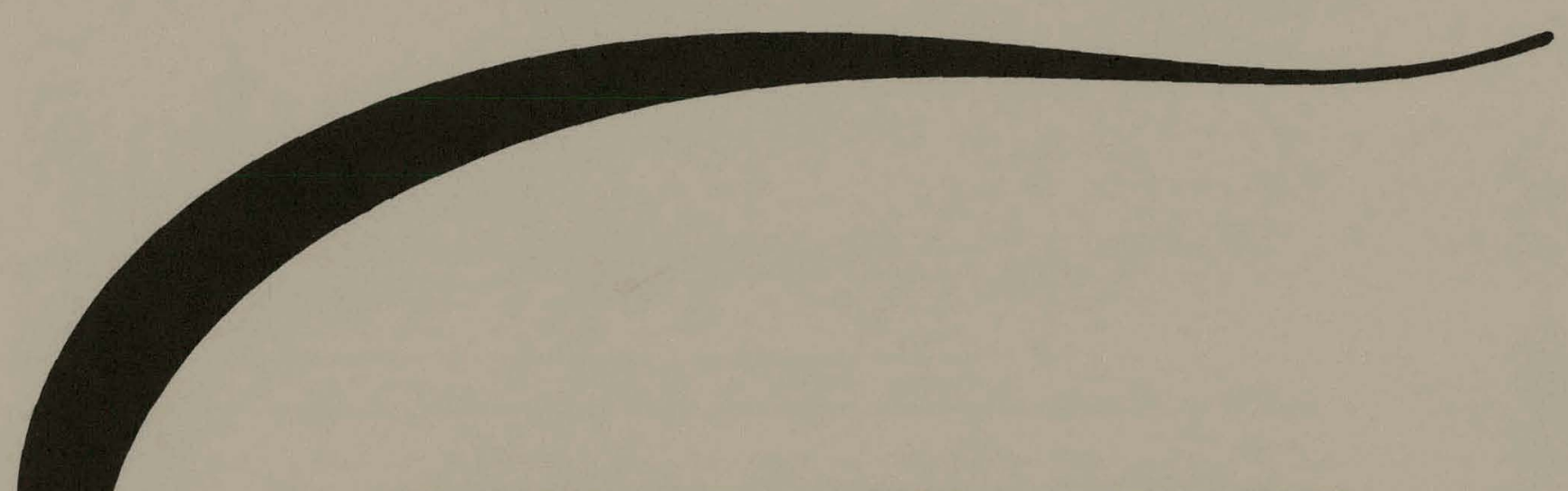

PREPARATION OF HIGH PURITY AMERICIUM OXIDE

Stephen G. Proctor

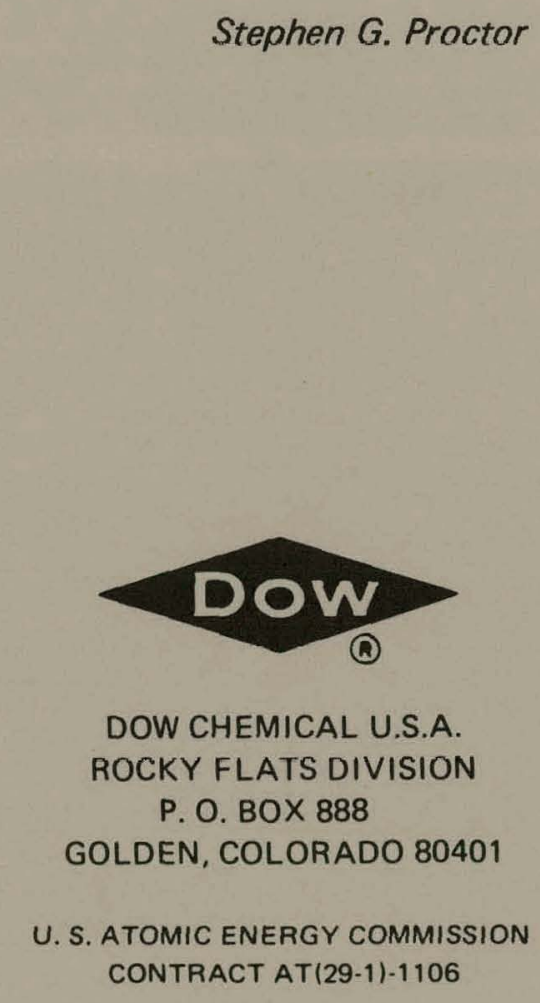




\section{DISCLAIMER}

This report was prepared as an account of work sponsored by an agency of the United States Government. Neither the United States Government nor any agency Thereof, nor any of their employees, makes any warranty, express or implied, or assumes any legal liability or responsibility for the accuracy, completeness, or usefulness of any information, apparatus, product, or process disclosed, or represents that its use would not infringe privately owned rights. Reference herein to any specific commercial product, process, or service by trade name, trademark, manufacturer, or otherwise does not necessarily constitute or imply its endorsement, recommendation, or favoring by the United States Government or any agency thereof. The views and opinions of authors expressed herein do not necessarily state or reflect those of the United States Government or any agency thereof. 


\section{DISCLAIMER}

Portions of this document may be illegible in electronic image products. Images are produced from the best available original document. 


\section{LEGAL NOTICE}

This repurl was preparcd as an account of wnrk sponsored by the United States Government. Neither the United States nor the United States Atomic Energy Commission, nor any of their employees, nor any of their contractors, subcontractors, or their employees, makes any warranty, expressed or implied, or assumes any legal liability or responsibility for the accuracy, completeness or usefulness of any information, apparatus, product or process disclosed, or represents that its use would not infringe privately owned rights.

Printed in the United States of America

Available from the

National Technical Information Service

U. S. Department of Commerce

Springfield, Virginia 22151

Price: Printed Copy $\$ 3.00$; Microfiche $\$ 0.95$ 


\title{
PREPARATION OF HIGH PURITY AMERICIUM OXIDE
}

\author{
Stephen G. Proctor
}

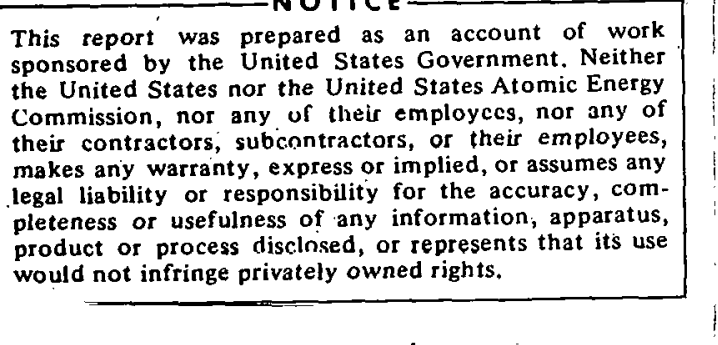

DOW CHEMICAL U.S.A.

ROCKY FLATS DIVISION

P. $0 . B O \times 888$

GOLDEN, COLORADO 80401

Prepared under Contract AT(29-1)-1106

for the

Albuquerque Operations Office

U. S. Atomic Energy Commission 
RFP-1857 


\section{O N T E N T S}

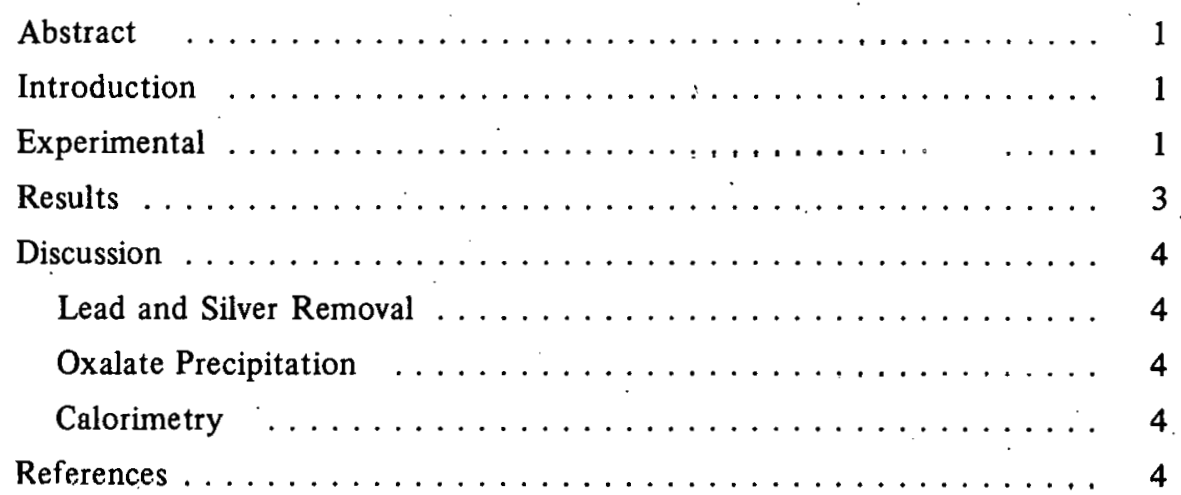


RFP-1857 


\title{
PREPARATION OF HIGH PURITY AMERICIUM OXIDE
}

\author{
Stephen G. Proctor
}

\begin{abstract}
Americium oxide has been purified using a fluoride percipitation of the rare earth impurities from a solution of hexavalent americium. Additional purification was obtained by successive oxalate precipitations of the americium. The total impurity content of the purified $\mathrm{AmO}_{2}$ averaged $600 \mathrm{ppm}$, none of which was contributed by the rare earth elements.
\end{abstract}

\section{INTRODUCTION}

Americium-241 has been considered a troublesome impurity in plutonium process streams. In recent years, however, there has been an increasing interest in americium-241 as a product in itself. Americium-241 is introduced into the plutonium as a result of the radiolytic decay of plutonium-241 which is present in minor quantities.

Plutonium-241 has a 13 year half-life and decays by beta emission to americium-241. The americium-241 derived from this source is therefore isotopically pure which enhances its value. For many years, americium-241 has been recovered from the Rocky Flats plutonium stream and has been shipped to the Research Isotope Pool at the Oak Ridge National Laboratory (ORNL).

The routine production grade $\mathrm{AmO}_{2}$ recovered by Rocky Flats will ordinarily contain from 0.5- to 5.0-wt\% impurities. These impurities will generally consist of lead, calcium, and the rare earth elements which constitute the major proportion of the impurity content. With the new interest in high purity $\mathrm{AmO}_{2}$, a purification procedure was developed to upgrade the production grade $\mathrm{AmO}_{2}$ to a 99.9\% level.

Many methods for purifying $\mathrm{AmO}_{2}$ have been reported. Weaver and Kappelmann used the Talspeak ${ }^{1}$ method of solvent extraction which used the highly preferential complexing of the americium by an aminopolyacetic acid. Many similar methods using the complexing of americium by organophosphorous chelating agents have been reported. By using an jou exchange technique, Ryan and Pringle ${ }^{2}$ were able to purify americium by making use of the americium thiocyanate complex which will load onto anion exchange resin. This procedure is currently used by Rocky Flats for the recovery and purification of americium.

Since the majority (75\%) of the impurities in the production grade $\mathrm{AmO}_{2}$ are rare earth elements, a method had to be used which would selectively separate the rare earths from americium. The similarities in the chemistries of the rare earths and americium make an effective separation difficult and most purification procedures do not yield a quantitative separation. Therefore, a new method of purification was developed. This method consisted of a fluoride precipitation of the rare earths from a solution of hexavalent americium, which does not form an insoluble fluoride.

The americium is initially oxidized from Am(III) to Am(VI) using ammonium persulfate and argentic oxide, Following oxidation, the rare earths are precipitated by introducing fluoride ion and the insoluble rare earth fluorides are removed from solution by filtration. The oxalate precipitation of the americium with oxalic acid will separate americium from most of the common elemental impurities which form soluble oxalate complexes.

\section{EXPERIMENTAL}

The $\mathrm{AmO}_{2}$ was divided into batches of approximately 20 grams, and each batch was treated identically for rare earth separation. The work was performed in one liter Pyrex beakers using a Thermolyne stirring hot plate. The calcination of the material was accomplished using a Thermolyne-type 1300 furnace.

Each batch was dissolved initially in $250 \mathrm{ml}$ of $8 M \mathrm{HNO}_{3}$ to give an americium concentration of $0.28 \mathrm{M}$. Following dissolution, the acidity of the solution was adjusted to $0.1 M$ with $8 M \mathrm{NH}_{4} \mathrm{OH}$. The solution was then heated to $80^{\circ} \mathrm{C}$ and made $0.25 \mathrm{M}$ in ammonium persulfate $\left[\left(\mathrm{NH}_{4}\right)_{2} \mathrm{~S}_{2} \mathrm{O}_{8}\right]$ and $0.002 \mathrm{M}$ in argentic oxide $\left(\mathrm{Ag}_{2} \mathrm{O}\right)$. The solution temperature was maintained at $80^{\circ} \mathrm{C}$ for 40 minutes to allow for complete oxidation of the americium to the hexavalent state. The solution volume at this point should be kept at 0.5 liter. The rare earths were then precipitated by making the solution $0.2 \mathrm{M}$ in HF. After mixing for approximately 3 minutes, the insoluble fluoride material was removed from solution by filtration and washed with water. The fluoride residue was calcined and set aside for recycling or discard. The americium in the resulting filtrate was reduced to the trivalent state by adding ascorbic acid until the brown color disappeared. The americium was then precipitated as an oxalate by adding a $0.1 M$ stoichiometric excess of oxalic acid and heating the solution to $60^{\circ} \mathrm{C}$. After an over-night-digestion period at room temperature, the americium oxalate $\left[\mathrm{Am}_{2}\left(\mathrm{C}_{2} \mathrm{O}_{4}\right)_{3}\right]$ was filtered, washed with water, and calcined at $600^{\circ} \mathrm{C}$ for 
6 hours. The resulting $\mathrm{AmO}_{2}$ was sampled for a rare earth impurity analysis.

Following the rare earth separation, the oxide was divided into $~ 50$-gram batches for lead and silver removal and a final oxalate precipitation. The $\mathrm{AmO}_{2}$ was dissolved in $500 \mathrm{ml}$ of $6 \mathrm{M} \mathrm{HNO}_{3}$, and made $0.1 \mathrm{M}$ in $\mathrm{NH}_{4} \mathrm{Cl}$. The resulting insoluble silver chloride $(\mathrm{AgCl})$ and lead chloride $\left(\mathrm{PbCl}_{2}\right)$ were removed from solution by filtration, washed with water, and discarded. The filtrate was subsequently treated with the previously described oxalate precipitation technique. The $\mathrm{Am}_{2}\left(\mathrm{C}_{2} \mathrm{O}_{4}\right)_{3}$ was again calcined to an oxide which was analyzed for impurities. A process flowsheet is shown in Figure 1.

Figure 1. Process' Flowsheet.

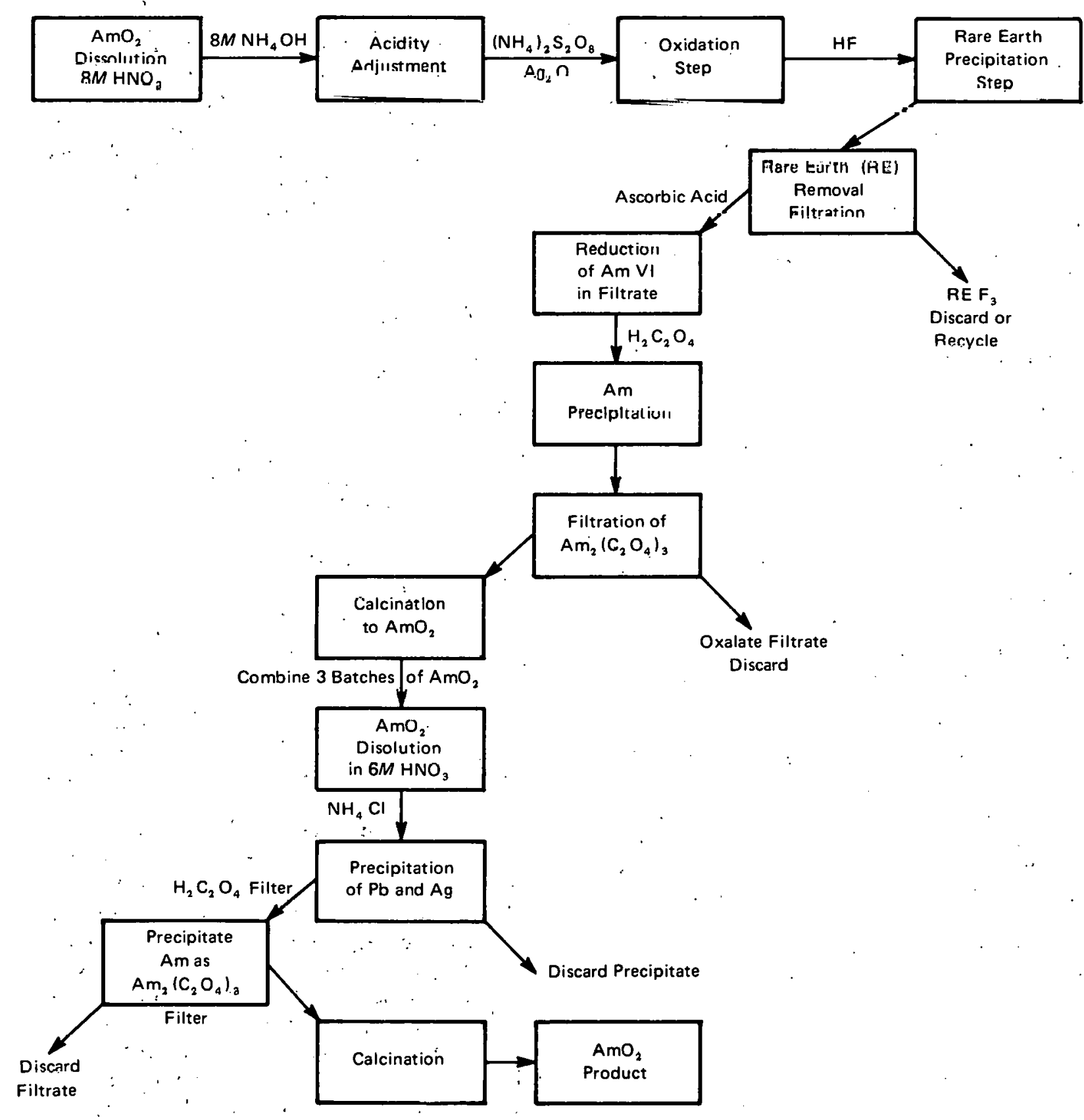




\section{RESULTS}

The $\mathrm{AmO}_{2}$ used in the first seven batches contained 5520 ppm of detectable impurities, of which $3300 \mathrm{ppm}$ was contributed by $2500 \mathrm{ppm}$ of lead and $800 \mathrm{ppm}$ of certain rare earths. The remaining $\sim 1700 \mathrm{ppm}$ of impurities were distributed fairly evenly among several common elemental impurities. The rare earth concentrations were erbium (Er) 100 ppm, thulium (Tm) 300 ppm, yttrium (Y) 300 ppm, and ytterbium (Yb) $100 \mathrm{ppm}$. The $\mathrm{AmO}_{2}$ used in the eighth and ninth batches contained large amounts of rare earth impurities. The rare earth concentration in these batches totaled $47,000 \mathrm{ppm}$, of which thulium contributed the bulk of $40,000 \mathrm{ppm}$. The individual rare earth concentrations in this $\mathrm{AmO}_{2}$ were thulium (Tm) 40,000 ppm; cerium (Ce) 700 ppm; neodymium (Nd) 3,000 ppm; yttrium (Y) 3,000 ppm; and ytterbium (Yb) 300 ppm.

The non-rare earth impurities in this $\mathrm{AmO}_{2}$ totaled $3,160 \mathrm{ppm}$ with lead and iron composing the bulk of this total. The results of the analysis after the rare earth removal for all nine batches are shown in Table 1.

Table 1. Rare Earth Impurities after Purification (ppm).

\begin{tabular}{|c|c|c|c|c|c|c|}
\hline $\begin{array}{c}\text { Batch } \\
\text { No. }\end{array}$ & $\mathrm{Ce}$ & $\mathbf{E r}$ & $\mathrm{Tm}$ & $\mathbf{Y}$ & $\mathrm{Yb}$ & Nd \\
\hline 1 & $<500$ & $<50$ & $<50$ & $<5$ & $<5$ & $<50$ \\
\hline 2 & $<500$ & $<50$ & $<50$ & $<5$ & $<5$ & $<50$ \\
\hline 3 & $<500$ & $<50$ & $<50$ & $<5$ & $<5$ & $<50$ \\
\hline 4 & $<500$ & $<50$ & $<50$ & $<5$ & $<5$ & $<50$ \\
\hline 5 & $<500$ & $<50$ & $<50$ & $<5$ & $<5$ & $<50$ \\
\hline 6 & $<500$ & $<50$ & $<50$ & $<5$ & $<5$ & $<50$ \\
\hline 7 & $<500$ & $<50$ & $<50$ & $<5$ & $<5$ & $<50$ \\
\hline 8 & $<500$ & $<50$ & $<50$ & $<5$ & $<5$ & $<50^{\circ}$ \\
\hline 9 & $<500$ & $<50$ & $<50$ & $<5$ & $<5$ & $<50$ \\
\hline Notes: & $\begin{array}{rr}<- \text { In } \\
\text { ppm }-\mu\end{array}$ & $\begin{array}{l}\text { less } \\
\text { aplii } \\
\text { purit }\end{array}$ & $\begin{array}{l}\text { detect } \\
\text { lysis. } \\
\text { m of } A\end{array}$ & $\mathrm{mi}$ & he er & \\
\hline
\end{tabular}

The ailalysis of the final $\mathrm{AmO}_{2}$ product is shown in Tables 2, 3 , and 4 . These results show that the detectable impurities for the first batch totaled $500 \mathrm{ppm}$, and the impurities for the second and third batches totaled $630 \mathrm{ppm}$ and $620 \mathrm{ppm}$, respectively. These three batches were made up by combining the nine batches into three batches. The impurity analyses were accomplished by optical emission spectroscopy. The calorimetiic assay for each of the three batches is shown in Table 5. All three batches compared favorably with the theoretical value of $0.8828 \mathrm{~g} \mathrm{Am} / \mathrm{g} \mathrm{AmO}$.

The average batch recovery as high purity $\mathrm{AmO}_{2}$ was $90.8 \%$, which was considered quite acceptable compared to Rocky Flats production losses of 10 to 15 percent. Individual batch recoveries ranged from 88 to 93 percent.
Table 2. Sample Analysis (ppm). Batch No. HP.71.1.

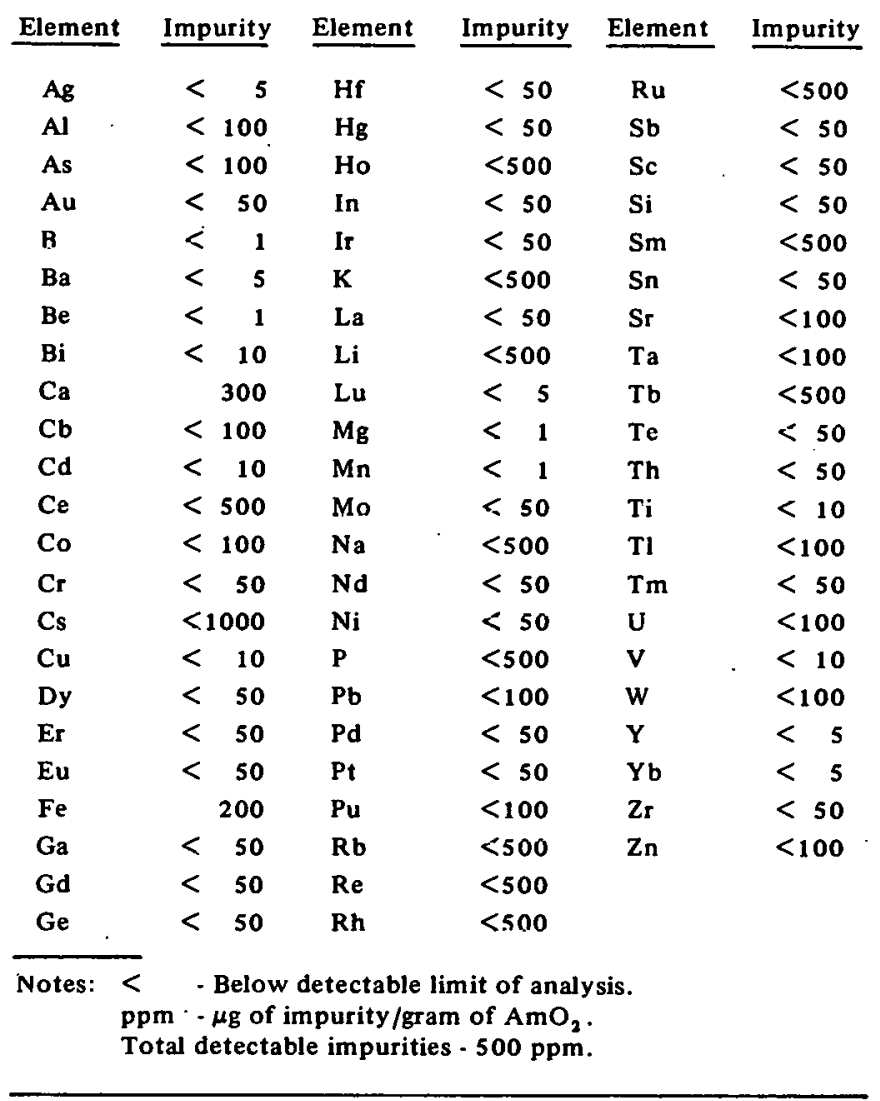

Table 3. Sample Analysis (ppm). Batch No. HP-71-2.

\begin{tabular}{|c|c|c|c|c|c|}
\hline Element & Impurity & Element & Impurity & Element & Impurity \\
\hline $\mathrm{Ag}$ & 80 & Hf & $<50$ & $\mathbf{R h}$ & $<500$ \\
\hline Al & $<100$ & $\mathbf{H g}$ & $<100$ & $\mathbf{R u}$ & $<500$ \\
\hline As & $<100$ & Ho & $<500$ & Sb & $<50$ \\
\hline $\mathrm{Au}$ & $<50$ & In & $<50$ & $\mathrm{Sc}$ & $<50$ \\
\hline B & $<$ & Ir & $<50$ & $\mathbf{S i}$ & $<10$ \\
\hline $\mathrm{Ba}$ & $<$ & K & $<30$ & $\mathrm{Sm}$ & $<500$ \\
\hline $\mathrm{Be}$ & $<$ & La & $<500$ & Sn & $<5$ \\
\hline $\mathrm{Bi}$ & $<10$ & $\mathbf{L i}$ & $<500$ & $\mathrm{Sr}$ & $<25$ \\
\hline $\mathrm{Ca}$ & 500 & $\mathbf{L u}$ & $<5$ & $\mathrm{Ta}$ & $<100$ \\
\hline $\mathbf{C b}$ & $<50$ & $\mathbf{M g}$ & $<10$ & $\mathrm{~Tb}$ & $<500$ \\
\hline $\mathrm{cd}$ & $<10$ & $\mathbf{M n}$ & $<1$ & $\mathrm{Te}$ & $<50$ \\
\hline $\mathrm{Ce}$ & $<500$ & Mo & $<50$ & Th & $<50$ \\
\hline Co & $<10$ & $\mathrm{Na}$ & $<500$ & $\mathbf{T i}$ & $<10$ \\
\hline $\mathrm{Cr}$ & $<10$ & Nd & $<50$ & TI & $<100$ \\
\hline Cs & $<1000$ & $\mathbf{N i}$ & $<50$ & $\mathrm{Tm}$ & $<50$ \\
\hline $\mathrm{Cu}$ & $<50$ & $\mathbf{P}$ & $<500$ & $\mathbf{U}$ & $<100$ \\
\hline Dy & $<300$ & $\mathbf{P b}$ & $<100$ & v & $<10$ \\
\hline Er & $\dot{<} 50$ & Pd & $<50$ & $w$ & $<100$ \\
\hline E.u & $<50$ & Pt & $<$ so & $\mathbf{Y}$ & $<5$ \\
\hline $\mathrm{Fe}$ & 50 & $\mathrm{Pu}$ & $<100$ & $Y_{b}$ & $<5$ \\
\hline Ga & $<500$ & $\mathbf{R b}$ & $<500$ & $\mathrm{Zr}_{\mathbf{r}}$ & $<\mathbf{5 0}$ \\
\hline $\mathrm{Ge}$ & $<5$ & $\operatorname{Re}$ & $<500$ & $Z_{\mathbf{n}}$ & $<50$ \\
\hline
\end{tabular}

Notes: $<-$ Below detectable limit of analysis. ppm - $\mu \mathrm{g}$ of impurity/gram of $\mathrm{AmO}_{2}$. Total detectable impurities $-630 \mathrm{ppm}$ 
Table 4. Sample Analysis (ppm). Batch No. HP-72-1.

\begin{tabular}{|c|c|c|c|c|c|}
\hline Element & Impurity & Element & Impurity & Element & Impurity \\
\hline $\mathrm{Ag}$ & 80 & Hf & $<50$ & $\mathbf{R h}$ & $<500$ \\
\hline $\mathrm{Al}$ & $<100$ & $\mathrm{Hg}$ & $<100$ & $\mathbf{R u}$ & $<500$ \\
\hline As & $<100$ & Ho & $<500$ & $\mathrm{Sb}$ & $<50$ \\
\hline $\mathrm{Au}$ & $<50$ & In & $<50$ & Sc & $<50$ \\
\hline B & $<1$ & $\mathbf{I r}$ & $<50$ & $\mathbf{S i}$ & 50 \\
\hline $\mathrm{Ba}$ & $<5$ & $\mathrm{~K}$ & $<30$ & $\mathrm{Sm}$ & $<500$ \\
\hline $\mathrm{Be}$ & $<$ & La & $<500$ & $\mathrm{Sn}$ & $<5$ \\
\hline $\mathbf{B i}$ & $<10$ & $\mathbf{L i}$ & $<500$ & $\mathrm{Sr}$ & $<25$ \\
\hline $\mathrm{Ca}$ & 440 & $\mathbf{L u}$ & $<5$ & $\mathbf{T a}$ & $<100^{\prime}$ \\
\hline $\mathrm{Cb}$ & $<50$ & $\mathrm{Mg}$ & $<10$ & $\mathrm{~Tb}$ & $<500$ \\
\hline $\mathrm{Cd}$ & $<10$ & Mn & $<1$ & $\mathrm{Te}$ & $<50$ \\
\hline $\mathrm{Ce}$ & $<500$ & Mo & $<50$ & Th & $<50$ \\
\hline Co & $<10$ & $\mathrm{Na}$ & $<500$ & $\mathbf{T i}$ & $<10$ \\
\hline Ćr & $<\quad 10$ & Pd & $<50$ & Tl & $<100$ \\
\hline Cs & $<1000$ & $\mathrm{Ni}$ & $<50$ & $\mathrm{Tm}$ & $<50$ \\
\hline $\mathrm{Cu}_{4}$ & $\ulcorner\quad 50$ & $\mathbf{P}$ & $<500$ & $\mathrm{U}$ & $<100$ \\
\hline Dy & $<500$ & $\mathbf{P b}$ & $<100$ & $\ddot{v}$ & $<10$ \\
\hline Er & $<50$ & Pd & $<50$ & $w$ & $<100$ \\
\hline $\mathbf{E u}$ & $<50$ & Pt & $<50$ & $\mathrm{Y}$ & $<5$ \\
\hline $\mathrm{Fe}$ & 50 & $\mathbf{P u}$ & $\therefore 100$ & $Y b$ & $<5$ \\
\hline $\mathbf{G a}$ & $<500$ & $\mathrm{Rb}$ & $<500$ & $\mathrm{Zr}$ & $<50$ \\
\hline $\mathrm{Ge}$ & $<5$ & $\mathbf{R e}$ & $<500$ & $\mathrm{Zn}$ & $<50$ \\
\hline Notes: & $\begin{array}{l}<\quad-\text { Belo } \\
\text { ppm - } \mu \text { g o } \\
\text { Total detec }\end{array}$ & $\begin{array}{l}\text { detectabl } \\
\text { npurity } / g \\
\text { le impur }\end{array}$ & $\begin{array}{l}\text { limit of ar } \\
\text { im of Aml } \\
\text { ies - } 620\end{array}$ & & \\
\hline
\end{tabular}

Table 5. Calorimetric Assays of $\mathrm{AmO}_{2}$.

\begin{tabular}{|c|c|c|c|}
\hline Batch No. & Grams of $\mathrm{AmO}_{2}$ & Grams of Am & $\begin{array}{l}\text { Grams Am/ } \\
\text { Grams } \mathrm{AmO}_{2}\end{array}$ \\
\hline HP-71-1 & 50.1 & 44.2 & 0.882 \\
\hline HP-71-2 & 50.0 & 44.2 & 0.884 \\
\hline HP-72-1 & 50.2 & 44.3 & 0.883 \\
\hline
\end{tabular}

\section{DISCUSSION}

The procedure used for americium purification is rapid and carl be easily carried oul with a minimal amount of equipment and space. In contrast, any solvent extraction purification process would have required a considerable arnuunt of extraotion equipment. (such as extractors and separatory devices). Additionally, any solvent extraction process which utilizes organic solvents should be carried out in an inert atmosphere to mininize the fire hazard associated with organic solvents in a glovebox system. Ion exchange processes, such as used at Rocky Flats, generate large volumes of waste solutions and are better suited for bulk separation and purification of americium. The method which was used is designed for a small scale batch-type operation capable of handling batches of americium as large as 20 grams each. The rare earth separation tcchnique which was used yields a rare-earth- free product with a single precipitation except in cases where the rare earth concentration is extremely high. In this case, a double precipitation is required. The oxalate purification step often requires more than one precipitation to obtain a pure product. Both the fluoride and oxalate purification steps, however, can be carried out quickly and with a minimal amount of equipment.

\section{Lead and Silver Removal}

For the three batches processed, the lead removal step worked well. The original contamination was reduced from $2500 \mathrm{ppm}$ to $<100 \mathrm{ppm}$ in each batch. The silver, which was introduced into the process as an oxidizing agent, was also efficiently removed. The silver contamination in the $\mathrm{AmO}_{2}$ will run as high as $5000 \mathrm{ppm}$ prior to its removal. As the icsults show, the silver was reduced to $80 \mathrm{ppm}$ in two batches and to $<5 \mathrm{ppm}$ in the other batch.

\section{Oxalate Precipitation}

The oxalate precipitation step of the procedure reduced the elemental impurity level from $1200 \mathrm{ppm}$ to an average of $575 \mathrm{ppm}$. The bulk of the remaining impurities was contributed by calcium ( $300 \mathrm{ppm}, 440 \mathrm{ppm}$, and $500 \mathrm{ppm}$ for the three batches). Calciurn contamination in americium is difficult to separate by oxalate precipitation because calcium also forms a moderately insoluble oxalate $\left(\mathrm{CaC}_{2} \mathrm{O}_{4}\right)$. The calcium contamination was therefore not expected to be reduced significantly by this technique.

\section{Calorimetry}

The calorimetric assay on the final product gave results which were nearly identical with the theoretical assay of $\mathrm{AmO}_{2}$ (88.3\%). The second batch of $\mathrm{AmO}_{2}$ actually exceeded the theoretical assay of $\mathrm{AmO}_{2}$, but the margin of error involved amountcd to only $0.1 \%$. This small error can be attributed to analytical error since the method is known to be accurate only to $\pm 0.1 \%$. Three 50 -gram batches of $\mathrm{AmO}_{2}$ have been purified using this purification technique and have been shipped to the ORNL Research Isotope Pool for sale and distribution.

\section{REFERENCES}

1. B. T. Weaver and F. A. Kappelmann, Talspeäk: "A New Method of Separating Am and $\mathrm{Cm}$ from the La by Extraction from an Aqueous Solution of an Aminopolyacetic Acid Complex with Monoacidic Organophosphate or Phosphonate," ORNL-3559 (1964).

2. V. A. Ryan and J. W. Pringle, "Preparation of Pure Americium," USAEC RFP-130 (1960). 